\title{
Models for the Development of Work-readiness Skills for Students in Vietnamese Universities
}

\author{
Tran Le Huu Nghia \\ Melbourne Centre for the Study of Higher Education \\ University of Melbourne
}

\begin{abstract}
Complementing existing literature about how to develop generic skills (GS) for students effectively, this article will report on models that six Vietnamese universities developed to train students in GS. It will also analyse factors influencing the development of these models and discuss factors contributing to the effectiveness of each of these models. Content analysis of relevant documents and 69 interviews with key informants of the implementation revealed that despite sharing a similar concept for executing GS policy, these universities translated it into practice differently, in terms of implementation scale and the channels and pedagogical practices through which GS are imparted to students. The analysis showed that curriculum autonomy, university leadership, and connection with external stakeholders were pivotal for the adoption of these GS implementation models. It also indicated that institutional leadership that is capable of engaging stakeholders was key for the success of using these GS implementation models.
\end{abstract}

Keywords: generic skills; Vietnamese universities; policy implementation; implementation models; higher education; university leadership

\section{INTRODUCTION}

In recent years, there has been an increasing demand for universities to develop sufficient work skills for students so that they can effectively undertake work duties $[1,2]$.

As a response, universities paid more attention to developing generic skills (GS) for students, in addition to academic abilities [3-5]. Generic skills are defined as non-discipline specific skills that may be achieved through learning and can be applied in study, work, and life contexts [6]. These skills may include communication, teamwork, and problem solving skills, among many others. These skills have been found to increase graduates' employment outcomes and overall work performance, empower their lifelong learning abilities, prepare them for an unknown future and enable them to act for the social good [7]. Therefore, many initiatives that promote teaching and assessing GS in higher education (HE) have been recently launched [4, 8-10]

The literature, however, indicates that GS are inconsistently implemented with different approaches, curriculum types and pedagogical practices across HE systems and institutions. Such differences were found to be associated with differences in the national context, institutional visions and missions, and the underlying perception towards GS of stakeholders $[3,11]$. In addition, the literature suggests that most of the initiatives for GS development have been executed in Western societies where English is spoken as the first language. There have been hardly any studies on GS-related issues in the developing world as yet. For these reasons, Vietnam, a developing, non-English speaking country with a socio-economic, cultural and 
political context completely different from the West, provides a unique context for further investigation of issues related to GS implementation outside of the Western HE context.

Within the length of this article, implementation models that Vietnamese universities used to develop GS for students will be reported. The article also discusses factors that contribute to the development of these models and factors influencing the effectiveness of using these models. In this, the article contributes to existing literature regarding the diversity of strategies that universities around the world are using to develop GS for students. The identified models would provide options for universities with institutional contexts similar to that of Vietnamese ones to adopt for the execution of GS policy in their institutions.

\section{Context of GS implementation in Vietnamese HE}

\section{LITERATURE REVIEW}

Vietnam is a developing non-English speaking country whose HE system possesses some different characteristics from those in the West. The contemporary HE is strongly characterized by a Confucian HE model (Marginson, 2011) with socialist ideologies, and it also possesses many Confucian morals and Western educational heritages $[12,13]$. The general aim of the HE is to produce human resources with adequate skills and attributes to sustain the nation and to integrate globally [14].

Developing GS for university students has become an urgent mission for Vietnamese universities lately. After the Doi Moi Policy, Vietnam has experienced a high economic growth rate for many successive years and is on target to become an industrialized and modernized country by $2020[15,16]$. Unfortunately, recent studies have showed that there is a lack of graduates with adequate levels of work skills that enable them to perform work duties effectively [16-18]. Likewise, the process of international integration in Vietnam has been increasing, which can help the country elevate its competitiveness and at the same time expose it to several challenges if it does not have a strong, skilled labour force. After joining the World Trade Organization, signing the General Agreement on Trade Services [19], and becoming a member of the ASEAN Economic Community [20], Vietnam is subjected to free labour flows in and out of the country. It indicates that without skilled labour, Vietnam will not be able to sustain its local labour market and compete in regional or global ones. Therefore, the HE system is expected to produce graduates who possessed substantial specialized knowledge, technical skill and work skills to maintain the competitiveness for Vietnam.

In that context, the Ministry of Education and Training (MOET) has been committed to the quality of students' learning outcomes. The HE system has been undergoing unprecedented reforms since the early 2000s [12]. One of the central targets of the reforms is to increase the quantity and quality of university graduates, following the advice of the World Bank's consultation on planning human resources for the need of socio-economic growth in the coming years [21]. In 2010, the MOET issued the Guideline 2196/BGDĐT-GDĐH [22], which mandated Vietnamese universities to develop GS for students. As such, on top of developing GS for students as an aspiration for addressing socio-economic demands, developing GS has become a must-do initiative for all universities in Vietnam now. However, execution of reforms, including GS policy, would face numerous obstacles, including a lack of curriculum and institutional autonomy, inadequacy of qualified teachers, and insufficient resources, to name a few [12]. 
In short, developing GS for students has become relevant and important in Vietnamese HE. However, there have been very few studies that specifically investigate how GS policy has been realized in universities. This study, therefore, will focus on examining how GS are developed for Vietnamese university students, using the experiences and viewpoints of academics and university leaders, who are key agents in the process of developing these skills for students.

\section{Elements in GS implementation models}

The term 'GS implementation model' in this study refers to four elements associated with tasks in executing GS policy in a HEI: the conceptualization and the scale of the implementation, curriculum design, and pedagogical practices in place to impart those skills to students. The literature suggests that many factors are associated with these tasks, which create variances across GS implementation models.

Conceptualization of the implementation. The concept that a university adopts for GS implementation can shape its 'content'. Based on the concept adopted, HE institutions would select GS and develop these skills for students in line with the concept $[3,4,23]$. At the institutional level, HE institutions often adopted a concept with a due attention to characteristics of disciplines, institutional situation and national context [23]. At the personal level, different groups of stakeholders may have different perspectives about relevant GS to develop for students [4]; therefore, if universities adopt the perspective of a certain group of stakeholders, that group will play a major role in shaping the content of the implementation. However, in the current context of HE, as there is 'little space for dialogue and discussion' between those groups [4]. In most of the cases, perspectives of employers, academics and professional bodies are often taken into account. It means that GS implementation is predominantly conceptualized as developing skills that enhance students' learning or employability skills.

Scale of the implementation. The literature has documented that universities can execute GS policy on a university-wide scale [24]. It is often accompanied by a top-down leadership approach, which is argued to help the implementation progress harmoniously across disciplines and schools in the university. However, this type of leadership often fails to gain the 'buy-in' of academics because their perspective on GS implementation is often not taken into account, or it could also lead to implementation based on stakeholders' compliance. In contrast, some universities have put GS policy into practice on a program-wide scale [25], i.e. the implementation is restricted within one program, although all other programs in a university could also be executing GS policy, but independently from each other. It is most often coordinated using a bottom-up or top-down approach. Barrie, Hughes [4] observed that a GS bottom-up approach starts with academic initiatives for training students in GS in the classroom. They argued that this leadership approach may engage teachers with teaching and assessing GS, but it may not be widespread without institutional policies and incentives.

Channel to impart GS. Some studies have attempted to identify curriculum designs that universities used to impart GS to students [3-5]. Generally, universities appear to design GS curriculum based on their viewpoint about the nexus between GS and discipline-specific skills. If they perceive that there is a close connection between these types of skills, GS that have been selected based on the adopted GS implementation concept will be integrated and mapped across subjects of a curriculum and delivered to students within the context of a discipline by disciplinary teachers. This GS curriculum design is often referred to as an embedded curriculum or integrated curriculum $[3,4]$. The advantage of this curriculum design is students can link GS with discipline-specific skills; however, it may make the implementation less visible 
and thus may cause people to gradually disengage. Also, mapping GS into the curriculum is complicated, and delivery of GS together with discipline-specific skills would multiply workloads for teachers; therefore, it may provoke resistance from teaching staff [4].

In contrast, if they perceive that there is little or no connection between discipline-specific skills and GS, independent subjects or modules will be developed to impart GS to all students in the institution, regardless of their disciplines. These subjects or modules are delivered by skills experts and often categorized as extra-curricular activities or foundational studies that facilitate students' transitions into university life, to develop necessary skills so that they can study effectively in major subjects in later years, or prepare students with specific skills that may enable them to find jobs [3,4]. While the subjects may be simpler to design and organize teaching activities, students may not be able to link these GS with discipline-specific skills. Additionally, GS may not develop appropriately within the short time allotted for these subjects [3].

As such, each type of GS development curricula has advantages and disadvantages. These curricula not only decide the channel through which GS are imparted to students but also define the role and responsibilities of teachers involved in delivering the curricula. Therefore, institutional context is important for GS curriculum design and is influential to the success of delivering that curriculum [3].

Pedagogical method to impart GS. The student-centred learning approach has been recognized to be conducive to developing GS for students. Many researchers have experimented and confirmed positive results of their teaching of GS using project-based learning [26, 27]; community service learning [28], online and distance learning [29, 30] and work-integrated learning (WIL) [31, 32]. The literature also suggests the major obstacle for GS implementation at the subject level is teacher engagement, which has been found to be associated with their perception about the relevance of GS in their subjects, their GS expertise, institutional policy and incentives, student participation and teaching practicalities [4, 33, 34]. Therefore, in order to ensure a successful implementation of GS policy, it is important to develop teacher and institutional capacity, as well as consider a feasible pedagogical practice that fits well with the institutional context.

\section{RESEARCH METHODS}

In 2013 -2015, a study was conducted to investigated how GS policy was executed in Vietnamese universities as well as identify facilitators and inhibitors of the implementation. This article will report the implementation models developed to realize GS policy, analyze factors contributing to the development of such models as well as discuss advantages and disadvantages of these models.

The study was conducted as a qualitative multiple case study, which provides an opportunity to investigate the implementation in depth and within its real context as well as allowing the comparison of the implementation of GS across the cases to identify similarities and differences [35]. The study was narrowed down to investigate universities located in the South of Vietnam to ensure feasibility. However, this study involved universities that represented different types and institutional contexts of universities in the system by using a maximum variation sampling principle [36]. Based on the classification and history of universities [14, 37], three public and three private universities were recruited for this study (Table 1). 
The study focused on investigating the implementation of GS solely in the Business Administration program of the universities to preserve disciplinary distinctiveness [38]. Focusing on one program allowed the researcher to analyze the research issues in depth and more accurately compare results across the universities. The program was chosen because it was a popular program in Vietnamese universities and there was more evidence of GS implementation Schools of Economics than in other schools

The participants in each selected university were recruited using a snowball sampling technique [39], which allowed the researcher to approach key informants of GS implementation in a university based on the recommendation of another participant. In total, 69 university leaders, school leaders, disciplinary teachers ${ }^{1}$, and skills teachers ${ }^{2}$, as well as leaders and staff members of the Youth Union and its associates (YUA) ${ }^{3}$ were recruited (Table 1).

Data were collected via semi-structured interviews [40] as well as from relevant documents and policies that were either available on the university websites or provided by the participants [41]. A qualitative content analysis was employed to analyze the data [42]. On a case-by-case basis, all relevant data were transcribed and repeatedly reviewed for content. Passages relevant to roles of external stakeholders in association with tasks in the analytical framework were highlighted and coded. Then, comparing the codes across the cases was conducted to find similarities and differences in external stakeholders' roles in GS implementation across the universities. This step also involves evidence-based interpretation of factors influencing the roles and contributions of external stakeholders in developing GS for students across the six case studies. Finally, the results emerging from the analysis were organized into the final report.

\section{Table 1. A summary of participants and institutional context}

\begin{tabular}{|c|c|c|}
\hline Universities & Institutional context & Participants \\
\hline $\begin{array}{l}\text { University A } \\
\text { (public) }\end{array}$ & $\begin{array}{l}\text { Located in a regional city, University A is governed by the } \\
\text { MOET and the provincial authority in terms of academic affairs, } \\
\text { finance and administration. This structure is typical of public } \\
\text { regional universities in Vietnam. }\end{array}$ & $\begin{array}{l}4 \text { leaders, } 7 \text { teachers, } 1 \\
\text { YUA leader, and } 1 \text { YUA } \\
\text { staff member }\end{array}$ \\
\hline $\begin{array}{l}\text { University B } \\
\text { (public) }\end{array}$ & $\begin{array}{l}\text { Located in HCM City, a metropolitan city in Vietnam, University } \\
\text { B is considered one of the 'đại hoc trong điểm' (key universities } \\
\text { in Vietnamese HE system). It has qualified academics plus an } \\
\text { extensive network with industries, but unfortunately does not } \\
\text { have curriculum autonomy. A prestigious institution without } \\
\text { curriculum autonomy makes it a special case in this study. }\end{array}$ & $\begin{array}{l}4 \text { leaders, } 8 \text { teachers, } \\
\text { and } 1 \text { YUA leader }\end{array}$ \\
\hline $\begin{array}{l}\text { University C } \\
\text { (public) }\end{array}$ & $\begin{array}{l}\text { Located in an average-sized city, University C is considered one } \\
\text { of the eight 'đại hoc vùng' (the most important university in a } \\
\text { geographical region). It is directly governed by the MOET in } \\
\text { terms of academic affairs, funding and administration. } \\
\text { University C is well known for its recent innovations in } \\
\text { pedagogy and management practices. }\end{array}$ & $\begin{array}{l}3 \text { leaders, } 9 \text { teachers, } \\
\text { and } 1 \text { YUA leader }\end{array}$ \\
\hline
\end{tabular}

\footnotetext{
${ }^{1}$ Disciplinary teachers are teachers who teach specialized subjects in the Business Administration program.

${ }^{2}$ Skills teachers are teachers who teach subjects that train students in certain GS, such as communication skills, computer skills, and English skills, among others.

${ }^{3}$ The Youth Union is a socio-political organization established by Ho Chi Minh and under the Communist Party. It is installed in each school and university in Vietnam, and is in charge of political education and leading social engagement activities.
} 


\begin{tabular}{ll}
\hline $\begin{array}{l}\text { University D } \\
\text { (private) }\end{array}$ & Located in HCM City, University D was upgraded from a semi- \\
& public vocational college. It is among 37 private universities \\
& that was established or upgraded after the HERA was approved \\
& by the MOET in 2005. University D is supervised by the MOET, \\
& but was granted autonomy in curriculum and finance \\
& management. These privileges and the vocational education \\
& tradition make it a special case study.
\end{tabular}

University E Located in a regional city, University E is among 37 private (private) universities that was established or upgraded after the HERA was approved by the MOET in 2005. This university reports to the MOET and does not have curriculum autonomy. This university represents newly established private universities in Vietnam.
4 leaders, 5 teachers, and 1 YUA staff member
3 leaders, 6 teachers,
and 1 YUA staff member
University F Located in HCM City, University F is one of the first 17 private (private) universities in Vietnam that were established in the 1990s. The university is supervised by the MOET primarily in terms of academic affairs. It represents the longest-established private universities in Vietnam.

\footnotetext{
2 Disciplinary teachers are teachers who teach specialized subjects in the Business Administration program.

${ }^{3}$ Skills teachers are teachers who teach subjects that train students in certain GS, such as communication skills, computer skills, and English skills, among others.

4 The Youth Union is a socio-political organization established by Ho Chi Minh and under the Communist Party. It is installed in each school and university in Vietnam, and is in charge of political education and leading social engagement activities.
}

\section{FINDINGS}

\section{GS implementation strategies of the six universities}

The implementation strategy that each university in this study adopted to execute GS policy is summarized as follows:

University A. The School of Commerce and Business Administration first developed GS for students in 2002, aiming to increase student engagement in their studies at the university and the graduates' employment outcomes. In 2009, following a university-wide curriculum renewal, GS implementation in the school became more intensified. University and school leaders coordinated senior academics to select relevant GS and design skills subjects to impart learning and work-readiness skills to students. Due to the MOET's regulation of credit numbers at that time (120-140 credits for an undergraduate program), the school could only add English, computer and communication skills subjects (seven, three and two credits respectively, with a credit equivalent to 15 study periods of 45-50 minutes - as a conventional practice in Vietnamese universities) into the curriculum and leaves others as elective skills subjects. The skills subjects were taught by teachers in the school but were not connected to specialized subjects. Teachers outside of the School of Commerce and Business Administration taught foreign language and computer skills subjects. Disciplinary teachers of the Business Administration program had been encouraged to embed GS into their subjects where relevant, instead of being explicitly required to teach these skills. The interviewed teachers all stated that they used a 'student-centred teaching approach' for delivering their subjects. In addition, students had to take a compulsory internship in the final year. The YUA also organized extracurricular activities to create more opportunities for students to engage in developing GS in conjunction with the main curricula. The YUA often invited skills experts and successful 
businesspeople to the university to organize skills classes or to share business experiences with students, respectively. They also led community engagement activities so that students could develop social skills and service-oriented attitudes.

University B. University leaders suggested that before 2009, developing GS for the students had primarily been the responsibility of the YUA. The university also required students to obtain a certificate in English and 'soft-skills' as graduation requirements, which was provided by a recognized education provider in the city; thus, GS implementation had been relying heavily on external stakeholders. Aside from English and computer subjects (seven and three credits), which were taught to all students in the university regardless of their disciplines, there had been no subjects in the curriculum that specifically trained students in GS. The university leaders also suggested that they intentionally delayed executing the MOET's GS policy until 2015, when a number of institutional privileges came into effect, including curriculum autonomy. At the time of research, school leaders were directing teachers in the respective school to identify relevant GS, include them in the statement of learning outcomes, and prepare for the coming reform. In the School of Business Administration, a leader had identified and embedded the selected GS into a skills subject that aimed to enhance graduates' employment outcomes. Skills teachers would teach these skills subjects without direct connection to specialized subjects. Due to MOET's requirements for credit numbers, they prioritized GS that were more discipline-relevant in order to increase students' employment outcomes. Like in the School of Business Administration of University A, disciplinary teachers were encouraged to integrate GS into their subjects where relevant and feasible. They revealed that despite heavy teaching workloads, they attempted to use a 'student-centred learning approach' in delivering their subjects. Students were required to take a compulsory internship in a relevant sector at the end of their study as a capstone subject. The YUA leader reported that they had organized diverse activities to help students develop GS, mostly community engagement activities, charity work, and field trips to businesses.

University C. Similar to the case of University B, prior to 2013, University C focused on reforming its management practices and implementing student-centred pedagogy. This university prioritized developing English skills ( 20 credits, and then cut down to 10 credits due to fit with the MOET's new curriculum structure of 120-140 credits per undergraduate program) and computer skills ( 3 credits) for students. These skills subjects were taught to all students in the university, regardless of their disciplines. In late 2013, university leaders decided to expand GS implementation beyond English and computer skills to include GS that would enable and encourage students to engage with their studies at the university and to obtain employment upon graduation. As such, they agreed that in addition to extra-curricular activities, the YUA would coordinate at least one compulsory skills subject to all students in the university. At the same time, each school could design skills subjects to train students in GS that were relevant to the characteristics of the discipline, if applicable. The interviewed teachers of the School of Business all suggested that they had been trained in using studentcentred pedagogies, so they felt confident using these practices in their teaching. Students were required to undertake a compulsory internship in the final year of their degree program. Finally, the YUA leader reported that they had organized several skills classes and some career fairs to develop work-readiness skills for students, and led activities that enhanced students' social skills and service attitudes with the support of neighbouring provincial authorities.

University D. Using curriculum autonomy, leaders of University D replaced the year-based curriculum with a credit-based curriculum in 2006 and started to focus on developing skills that would empower students with their learning at the university and would improve their 
chance of employment. In 2010, leaders of University D founded the Department for General Education to deliver a co-curriculum of skills to all students in the first two years at the university. This Department coordinated nine skills subjects, but students were required to complete at least three out of the nine (nine credits). Students were also trained in English and computers skills (28 and three credits respectively). The skills teachers consistently suggested that they were trained on and required to use a WIL approach to deliver their subjects. The disciplinary teachers also reported that they were required to train students in GS alongside disciplinary knowledge, using a work-integrated approach. In addition, students were required to work or take two compulsory internships or submit evidence of equivalent work experience in local industries for exemption of the internships. Extra-curricular activities were frequently organized by the YUA as an additional channel for students to develop GS. A special feature of extra-curricular activities in University D was that the agenda and the 20 clubs were established and operated by the students themselves, and YUA leaders only gave support when necessary.

University E. In spite of not having curriculum autonomy, this University used a relatively similar implementation model to that of University D. In 2008, leaders of University E founded the School for General Science, and developed skills subjects to train all students in the first three years at the university. Like most universities in this study, they could only add communication skills, computer skills, and English skills subjects (two, three and 24 credits respectively) into the curriculum and left others as electives. Suggested by the rector and skills teachers, this skills curriculum aimed to train students in social values and skills that would enhance their learning and employment prospects. These skills subjects were taught without connection to specialized subjects. In the main curriculum, all disciplinary teachers were encouraged to train GS in conjunction with disciplinary knowledge. In addition, leaders of University E attempted to adopt work-integrated learning by employing successful qualified people from industries to teach skills and disciplinary subjects. However, as suggested by most participants, due to being a newly established university and being located in a regional city, employment of qualified industry-based teachers like this was difficult, and did not seem to help execute the WIL very effectively. Business students in the university also had to take a compulsory internship in a local industry. Alternatively, they could submit evidence of equivalent work experience for internship exemption. Like the previous universities, the YUA in this university organized some seminars where local employers and recruiters shared business experiences and helped students with concerns about employment. The YUA also led some career fairs, charity work and social engagement activities.

University F. At the time of research, English and computer subjects (four and 10 credits) were taught to all students in the university. The university leaders suggested that they were finalizing the process to transfer its status from being a people-founded university to nonpublic. Therefore, as the rector stated, each school in the university was encouraged to execute GS policy in their own way, so that students' employment outcomes could be enhanced. In his opinion, that was why the university experienced different levels of progress in the implementation between the schools. At the School of Business Administration, disciplinary teachers all stated that they had recommended adding skills subjects into the curriculum to train students in skills that would enhance their engagement with studies and employment opportunities; unfortunately, the Dean rejected it, explaining that the graduates' employment outcomes had already been high for many successive years. However, he encouraged disciplinary teachers to teach GS to students where they could. Both skills and disciplinary teachers suggested that they used a student-centred approach in their teaching. Students were 
required to take a compulsory internship as part of their study. The YUA leader stated that they had greatly contributed to developing GS for students in the school. Under the YUA leadership, a variety of clubs were established, which not only helped advance students' discipline-specific knowledge and skills, but also nurtured their generic and social engagement skills. The YUA also provided career consultation services and connected students with employers by organizing career fairs, meetings with successful business people, and field trips to companies and enterprises.

\section{GS IMPLEMENTATION MODELS IN VIETNAMESE UNIVERSITIES}

At this point, the GS implementation strategy of each university has been identified. In this section, similarities and differences in the conceptualization and scale of the implementation and the channels and pedagogical practices through which GS were imparted to students will be analyzed to find a general model for executing GS policy

Conceptualization. Although there were slight differences in selecting relevant GS to develop for students, all six Vietnamese universities had at least one of two goals when developing GS for students: (i) enhancing students' engagement with their university studies and (ii) improving their graduates' employment outcomes. However, when considering the two aims, they complement each other. The former could contribute to the latter by improving students' learning outcomes. Therefore, the main concept of GS implementation in Vietnamese universities was equipping them with skills to obtain a job and efficiently perform work duties, i.e. developing work-readiness skills for students.

Implementation scale. Findings from the case studies showed that to translate the concept into practice, top-level leaders of Universities $\mathrm{C}, \mathrm{D}$ and $\mathrm{E}$ directly coordinate the implementation university-wide in their institutions. In contrast, top-level leaders of Universities A, B and F allowed mid-level university leaders to put GS policy into practice in their respective school, i.e. GS implementation in these universities was executed on a schoolwide scale.

GS imparting channels. In this study, it showed that GS were imparted to students via two channels. On the one hand, via curriculum-based activities, GS were developed for students within skills subjects. However, most of them could not develop all of the selected GS via this channel. Therefore, to make it up for not being able to impart GS adequately to students via curriculum-based activities, all six universities involved extra-curricular activities organized by the YUA as another channel to develop GS for students. The findings also showed that four universities (A, B, C, and F) appeared to use extra-curricular activities as the main channel through which students could develop GS. The other two universities (D and E) attempted to train students in GS via curriculum-based activities, and extra-curricular activities were an additional channel.

GS imparting pedagogical methods. Participants from Universities A, B, C, F reported that they were using a student-centred approach in delivering their subjects, including skills subjects, to students, and a compulsory internship - a form of WIL - to train students in both GS and discipline-specific skills. In addition, Universities D and E attempted to use a WIL approach in executing GS policy, both in the classroom and via the internship.

As such, the analysis revealed a common GS implementation model that the six Vietnamese universities used to execute GS policy. GS were developed for students with a focus on improving students' work-readiness skills. The concept was put into practice on a university or 
school-wide scale via curriculum-based and extra-curricular activities using student-centred pedagogies, including the WIL. However, the way these universities translated that concept into practice created some variances from the original implementation models. Based on differences and similarities of the four elements of the implementation, three models can be identified and presented in Table 2 .

Table 2. GS implementation models in Vietnamese universities

\begin{tabular}{|c|c|}
\hline Model & Description \\
\hline $\begin{array}{l}\text { School-wide, extra- } \\
\text { curriculum-based model }\end{array}$ & $\begin{array}{l}\text { - Implementation concept: developing work-readiness skills } \\
\text { - } \quad \text { School-wide scale implementation }\end{array}$ \\
\hline $\begin{array}{l}\text { University A } \\
\text { University B }\end{array}$ & $\begin{array}{l}\text { - Extra-curricular activities were the principal channel through } \\
\text { which GS were developed for students; curriculum-based } \\
\text { activities were a complementary channel }\end{array}$ \\
\hline University F & $\begin{array}{l}\text { - Student-centred pedagogies and a compulsory internship (WIL) } \\
\text { were used to impart GS; skills subjects were taught without } \\
\text { connection to disciplinary context; GS were not explicitly taught } \\
\text { and assessed in specialized subjects. }\end{array}$ \\
\hline
\end{tabular}

\section{University-wide, extra- curriculum-based model}

University C
- Implementation concept: developing work-readiness skills

- University-wide scale implementation

- Extra-curricular activities were the principal channel through which GS were developed for students; curriculum-based activities were a complementary channel

- $\quad$ Student-centred pedagogies and a compulsory internship (WIL) were used to impart GS; skills subjects were taught without connection to disciplinary context; GS were not explicitly taught and assessed in specialized subjects.

\section{University-wide, curriculum- based model}

University D
- Implementation concept: developing work-readiness skills

- University-wide scale implementation

- Curriculum-based activities were the principal channel through which GS were developed for students; extra-curricular activities were a complementary channel

- WIL were used to impart GS (in the classroom and via internships); skills subjects were taught independently in the first two years but linked with specialized subjects; GS were explicitly taught and assessed in specialized subjects.

The model that University C used was a variance of the model used by Universities A, B and F, as this university implemented GS policy on a university-wide scale whereas the other three executed the policy on a school-wide scale. University D and E had a minor difference in the roles students played (leaders versus followers) in the YUA extra-curricular activities; however, this difference did not deviate from the four major elements used to categorize GS implementation models. Such a variance in practice appeared to result from the curriculum autonomy and connection with external stakeholders that each university had, as well as university leadership. These factors will be examined in the Discussion section.

\section{DISCUSSION}

This article attempts to identify models that Vietnamese universities used to implement GS policy in their institution, as well as to analyze factors influencing the adoption of these models. Until now, GS implementation models have been identified. This section will continue 
to discuss factors influencing Vietnamese universities to adopt these models for executing GS policy. While doing so, it will also discuss factors that contributed to the effectiveness of the use of the models. The discussion would lead us to some useful lessons when implementing GS policy in HE.

The main concept of GS implementation in Vietnamese universities was developing workreadiness skills for students, which was in line with the purpose of Vietnamese HE as defined in the HE Law [14]. It was predictable because Vietnamese universities are strongly influenced by the MOET. This alignment between GS implementation concept and the HE purpose supports the discussion at the B-HERT roundtable in Australia that GS implementation was linked with the defined purpose of HE [43]. This concept also fit with Vietnamese universities' aspirations to address socio-economic demands for skills in the labour market $[17,18]$. In a country of Confucian heritage like Vietnam; students' learning is often dependent on teachers [44]; therefore, when entering universities, they face a different learning environment where a high level of intellectual skills and independent learning are essential. As such, they need support to develop adequate skills so that they can integrate into the academic environment of the university and more effectively engage with their learning. Likewise, Vietnamese parents are overprotective to their children; therefore, most of them lack essential life skills as well as skills that enable them to work [45]. Those factors created a lack of work skills in Vietnamese graduates, and developing work skills for university students has become urgent and critical in Vietnamese HE.

In addition, the scale of the implementation appeared to depend on the leadership of each university. It was evident from the six case studies that top-down leadership and management, which is a conventional practice in the $\operatorname{HE}$ system $[46,47]$, was used to coordinate implementation tasks and to get stakeholders involved in the implementation. However, it was exercised differently across the six case studies. In Universities C, D and E, top-level university leaders coordinated the implementation on an institution-wide scale. As explained by some participants and leaders from these universities, this leadership practice would cause the implementation to proceed consistently between different schools and programs. As such, they prioritized a harmonious implementation without considering the linking of GS with specialized skills. In contrast, top-level leaders of Universities A, B and F allowed mid-level university leaders to put GS policy into practice in their respective school, i.e. GS implementation in these universities was executed on a school-wide scale. This leadership approach, as stated by two university leaders, was to make GS implementation fit more successfully into the context of each discipline or school. These findings indicate those leaders' perceptions about the connection between GS and specialized skills could have influenced on their decision regarding the implementation scale.

Moreover, in this study, it showed that GS were imparted to students via two channels: curriculum-based activities and extra-curricular activities. From participants' perspectives, institutional contexts affected their adoption of these channels for realizing GS policy. Firstly, aside from University D, leaders of the other universities reported that without curriculum autonomy, they had to comply with the MOET's regulation of 120-140 credits per undergraduate program. Adding more skills subjects into the curriculum would mean having fewer credits available for specialized subjects. Therefore, they had to prioritize some GS subjects and leave others as electives. It also meant that in these universities, curriculum-based activities were inadequate for developing GS for students. University D had curriculum autonomy, so it was easier for it to modify the curricula to develop GS for students. Secondly, the YUA extra-curricular activities were involved in order to develop GS for student apart from 
curriculum-based activities. This was because the YUA had extensive experience in successfully leading social engagement activities in Vietnamese universities for decades. As reported in the case studies, the YUA helped develop GS for students via organizing classes for CV writing, job interview skills, community engagement activities, career fairs and career consultation services to students. As such, being an integral component of the implementation model, these extra-curricular activities were aligned with the main concept of the implementation. Participants reported that via this channel, students could remarkably improve their GS. From what participants reported, extra-curricular activities were the main channel through which GS policy was executed in Universities A, B, C, and the School of Business of University F at the time of research. In contrast, they were an extra source for executing GS policy in Universities D and E, where university leaders attempted to develop GS for students via curriculum-based activities. Findings related to GS imparting channels suggest three things: (i) curriculum autonomy was a major factor that determines whether GS can be developed via curriculumbased activities or not; (ii) extra-curricular activities are conducive for students to develop their GS, so these activities should be exploited more effectively; and (iii) if universities were to develop GS for students via combined channels, these channels must complement each other and align with the concept of the implementation.

Furthermore, GS were imparted by different pedagogical practices. Participants in four universities reported that they were using a student-centred approach in delivering their subjects, including skills subjects, to students. They also used internships, a form of WIL, to train students in both GS and discipline-specific skills. The use of 'student-centred learning approach' in translating GS policy into practice is predictable because this approach has been found to be conducive for students' development of GS [27, 31, 32]. Also, in recent years, the MOET has launched several initiatives to help teachers in Vietnamese universities stay away from the traditional theory-based pedagogical practice to engaging with using more active teaching-learning activities in the classroom [44]. Under the student-centred approach, the use of WIL, in forms of a compulsory internship, has long been used in Vietnamese universities. In participants' views, it was where students could develop the most relevant GS for their future career. In addition, Universities D and E attempted to use a WIL approach, also under the student-centred approach, in executing GS policy, both in the classroom and via the internship. For both universities, their institutional visions were to produce skilled graduates that meet employers' demands. They recruited teachers with relevant industrial experience and train teachers in pedagogical practices to deploy the use of WIL. This pedagogical practice was innovative and also risky, concerning the fact that not many Vietnamese universities have extensive connections with industries and academics are not adequately qualified and may not have experiences working in industries $[44,48]$. As such, the adoption of pedagogical practices to impart GS to students appeared to depend on teacher capacity and connections with industries a university had. At this point, factors influencing the adoption of implementation models in Vietnamese universities have been discussed, including:

- the defined purpose of the HE;

- socio-economic and cultural issues in the country;

- university leadership convention;

- university leaders' perception of the nexus between GS and specialized skills;

- the level of curriculum autonomy that Vietnamese universities have;

- the roles of the YUA extra-curricular activities in Vietnamese universities;

- teacher capacity; and

- connections with industries 
The remaining issues are which model yielded success and what factors contributed to that success. The evidence showed that out of the six universities, which represent Vietnamese universities of different institutional contexts, these models have progressed and yielded different outcomes. University D appeared to make GS implementation progress far more the others and have obtained great initial successes. Participants from this case consistently viewed that GS implementation in their university was successful. Surveying their graduates, the university reported that they had achieved from 75 to 90 percent of graduates' employment in the past five years. Likewise, surveying employers in the city about their graduates' work performance, university leaders proudly revealed that employers were satisfied with the way their graduates worked, commenting that they possessed better work skills than graduates from other universities. Participants in this case study attributed the success to the curriculum autonomy that enabled them to modify the curricula to embed skills relevant for students' future work life, to the connections with industries that helped them deploy the WIL successfully, and to the university leadership that was capable of engaging people in tasks for the implementation via effective communication of GS policy and implementation strategy, building teacher capacity and allocating adequate resources and support to GS development activities.

The other five universities experienced different levels of achievement in the implementation process. The main factor that inhibited the implementation, in the view of most participants, was that institutional leadership failed to engage stakeholders with the implementation. For example, disciplinary teachers did not hear about GS policy, did not know their roles in the implementation, and/or faced problems related to teaching practicalities such as class sizes, heavy workload, and poor teaching systems. YUA leaders commented that the role of extracurricular activities in the implementation of GS was not acknowledged by students or the academic community, and very few resources were allocated for their operation. These were consistent with top-level university leaders' comments that there was fragmented implementation across schools or units in their universities. Similarly, the analysis showed that leaders of University E adopted an implementation model, which was not feasible with its institutional capacity. This was due to being a newly established regional institution; it had not yet built a teacher capacity that was strong enough to deploy the WIL in the classroom. Without an extensive connection with industries, it failed to recruit experts from industries for classroom-based WIL approach, and reduced opportunities for student internships. Likewise, leaders of the School of Business Administration of University F halted the implementation via curriculum-based activities. Findings from these cases confirm that regardless of implementation models a university adopts for executing GS policy, institutional leadership is a significant factor for the success of the implementation, at least in the context of contemporary Vietnamese HE where GS implementation was competing with many simultaneously occurring reforms [12].

\section{CONCLUSION}

This study found that GS implementation in Vietnamese universities was conceptualized as developing work-readiness skills for student. The concept was translated into practice via both curriculum-based and extra-curricular activities using a student-centred approach, which included the WIL. The analysis showed that the adoption of GS implementation models in these universities was influenced by socio-economic and cultural context of the country, the HE purpose, university leaders' perceptions of the nexus between GS and specialized skills, university leadership convention, the level of curriculum autonomy, as well as other institutional advantages that they had, which also created variances in the model across universities. The analysis also showed that curriculum autonomy, connections with external 
stakeholders, and effective leadership that was capable of engaging stakeholders and harnessing institutional advantages were the three major factors that could influence the effectiveness of the GS implementation model. Although the study is most relevant to Vietnamese universities, the implementation model identified in this article can be useful for universities that are struggling with developing GS for students. It is recommended that extracurricular activities should an integral component of the institutional GS implementation model and that university leadership must be improved to most efficiently coordinate the implementation. Future studies should examine how these models work, as well as factors influencing the effective use of the model.

\section{ACKNOWLEDGEMENTS}

This study was funded by the Endeavour Scholarship and Fellowship Program, Australian Government. The author acknowledges thoughtful comments and advice on earlier drafts from Associate Professor Sophie Arkoudis, Doctor Ryan Naylor and the anonymous reviewers. I am grateful to all of the participants and those who have supported me with the project.

\section{References}

1. Carnevale, A.P. and N. Smith, Workplace basics: the skills employees need and employers want. Human Resource Development International, 2013.16(5): p. 491-501.

2. Hurrell, S.A., Rethinking the soft skills deficit blame game: Employers, skills withdrawal and the reporting of soft skills gaps. Human Relations, 2016.69(3): p. 605-628 24p.

3. Al-Mahmood, R. and P. Gruba, Approaches to the implementation of generic graduate attributes in Australian ICT undergraduate education. Computer Science Education, 2007.17(3): p. 171-185.

4. Barrie, S., et al., National GAP issues papers, 2009: Australia. Available from http://www.itl.usyd.edu.au/projects/nationalgap/resources/GAPpdfs/NationalGAP_issues_Papers.pdf

5. Jääskelä, P., S. Nykänen, and P. Tynjälä, Models for the development of generic skills in Finnish higher education. Journal of Further and Higher Education, 2016: p. 1-13.

6. Tertiary Education Quality and Standards Agency, Australian qualifications framework, 2013, The Australian Qualifications Framework Council Australia.

7. Hager, P. and S. Holland, Graduate attributes, learning and employability. Lifelong learning book series: v. 62006, Dordrecht, Netherlands: Springer.

8. González, J. and R. Wagenaar, Tuning educational structures in Europe2003, Bilbao: University of Deusto

9. Coates, H. and S. Richardson, An international assessment of bachelor degree graduates' learning outcomes. Higher Education Management and Policy, 2012. 23(3): p. 1-19.

10. Shattock, M.L., Impact of the Dearing Report on UK higher education, in International Handbook of Lifelong Learning, D. Aspin, et al., Editors. 2001, Springer: Dordrecht. p. 7-17.

11. Barrie, S., C. Hughes, and C. Smith, The national graduate attributes project: integration and assessment of graduate attributes in curriculum, 2009: Australia.

12. Harman, G., M. Hayden, and T.N. Pham, Higher education in Vietnam: reform, challenges and priorities2010, The Netherlands: Springer.

13. Pham, L.H. and G.W. Fry, The emergence of private higher education in Vietnam: Challenges and opportunities. Educational Research for Policy and Practice, 2002. 1(1-2): p. 127-141.

14. Vietnamese National Congress, Luật giáo dục đại học, 2012, Vietnamese National Congress: Hanoi.

15. World Bank, Vietnam, World Bank, Editor 2015. Available from

http://data.worldbank.org/country/vietnam

16. World Bank. Vietnam: Higher education and skills for growth. 2008 [cited 2015 08/04]; Available from: https://openknowledge.worldbank.org/handle/10986/7814. 
17. Bodewig, C., R. Badiani-Magnusson, and K. Macdonald, Skilling up Vietnam: Preparing the workforce for a modern market economy2014: World Bank Publications.

18. Manpower Group, Building a high-skilled economy: A new Vietnam, 2011.

19. Varghese, N.V., GATS and higher education: the need for regulatory policies, 2007, UNESCO. p. 26.

20. The Association of Southeast Asian Nations, ASEAN Econmic Community blueprint 2008: Jakarta, Indonesia.

21. Pham, T.N., The higher education reform agenda: A vision for 2020, in Reforming higher education in Vietnam: Challenges and priorities, G. Harman, M. Hayden, and Pham Thanh Nghi, Editors. 2010, Springer: The Netherlands. p. 51-64.

22. MOET, Công văn 2916/ BGDĐT-GDĐH hướng dẫn xây dựng và công bố chuẩn đầu ra ngành đào tạo, 2010, Ministry of Education and Training: Hanoi.

23. Pitman, T. and S. Broomhall, Australian universities, generic skills and lifelong learning. International Journal of Lifelong Education, 2009. 28(4): p. 439-458.

24. Fleming, J., et al., A whole of university approach to embedding graduate attributes: A reflection, in Global Challenges and Perspectives in Blended and Distance Learning, J. Willems, B. Tynan, and R. James, Editors. 2013, Information Science Reference: Hershey, PA. p. 246-257.

25. O'Neill, G., A program wide approach to assessment: A reflection on some curriculum mapping tools, in AISHE 2009 Conference2009: Dublin, Ireland.

26. Moalosi, R., S. Molokwane, and G. Mothibedi, Using a design-orientated project to attain graduate attributes. Design and Technology Education, 2012. 17(1): p. 30-43.

27. Jollands, M., L. Jolly, and T. Molyneaux, Project-based learning as a contributing factor to graduates' work readiness. European Journal of Engineering Education, 2012. 37(2): p. 143-154.

28. O'Connor, K.M., K. Lynch, and D. Owen, Student-community engagement and the development of graduate attributes. Education \& Training, 2011. 53(2-3): p. 100-115.

29. Lewis, R., Teaching via video conference - comments and observations and the attainment of graduate attributes and learning outcomes, in Australasian Association for Engineering Education Conference 2011: Developing engineers for social justice: Community involvement, ethics \& sustainability2011, Engineers Australia: Barton, ACT. p. 625-632.

30. Brodie, L., Delivering key graduate attributes via teams working in virtual space. International Journal of Emerging Technologies in Learning, 2011. 6(3): p. 5-11.

31. Rauchle, M. and G. Reddan, Student perceptions of the value of career development learning to a workintegrated learning course in exercise science. Australian Journal of Career Development, 2012. 21(1): p. 38-48.

32. Smith, C. and K. Worsfold, Unpacking the learning-work nexus: 'priming' as lever for high-quality learning outcomes in work-integrated learning curricula. Studies in Higher Education, 2015. 40(1): p. 22-42.

33. de la Harpe, B. and C. David, Major influences on the teaching and assessment of graduate attributes. Higher Education Research and Development, 2012. 31(4): p. 493-510.

34. Jones, A., Generic attributes as espoused theory: The importance of context. Higher Education, 2009. 58(2): p. 175-191.

35. Yin, R.K., Case study research : design and methods. 4 ed. Applied social research methods series: v. 52009, Thousand Oaks, California: Sage.

36. Merriam, S.B., Qualitative research : a guide to design and implementation. Jossey-Bass higher and adult education series2009, San Francisco Jossey-Bass.

37. Pham, L.T., Mô hình đại học trọng điểm trong khu vực ngoài công lập, 2015.

38. Jones, A., Generic attributes in Accounting: The significance of the disciplinary context. Accounting Education, 2010.19(1/2): p. 5-21.

39. Browne, K., Snowball sampling: using social networks to research non-heterosexual women. International Journal of Social Research Methodology, 2005. 8(1): p. 47-60. 
40. Horton, J., R. Macve, and G. Struyven, Qualitative research: experiences in using semi-structured interviews, in The real life guide to accounting research, C. Humphrey and B. Lee, Editors. 2004, Elsevier Science: Amsterdam, The Netherland. p. 339-357.

41. Prior, L., Using documents in social research2003, London: UK: Sage.

42. Elo, S. and H. Kyngäs, The qualitative content analysis process. Journal of advanced nursing, 2008. 62(1): p. 107-115.

43. B-HERT, B-HERT News: Developing generic skills: Examples of best practice, 2003. Available from http://www.bhert.com/publications/newsletter/B-HERTNEWS16.pdf

44. Harman, G. and T.N.B. Nguyen, Reforming teaching and learning in Vietnam's higher education system in Reforming higher education in Vietnam: Challenges and priorities, G. Harman, M. Hayden, and Pham Thanh Nghi, Editors. 2010, Springer: The Netherlands. p. 65-86.

45. Tran, N.T., Vietnamese parents' attitudes towards Western parenting behaviours and intervenstions, 2013, Vanderbilt University.

46. Marginson, S., Higher education in East Asia and Singapore: rise of the Confucian Model. Higher Education, 2011.61(5): p. 587.

47. Nguyen, T.L.H., Middle-level academic management: A case study on the roles of the heads of department at a Vietnamese university. Tertiary Education and Management, 2013. 19(1): p. 1-15.

48. Tran, N.C., Reaching out to society: Vietnamese universities in transition. Science \& Public Policy, 2009. 36(2): p. 91-95. 